\section{Ructions about twelve-year tenure limit}

Senior scientists in France were staggered last week to learn that they may remain as research directors - heads of laboratories or research groups - for no more than 12 years. The new regulation, announced by science and industry minister Jean-Pierre Chevènement, will be applied retroactively from 31 December 1985. Hence any director who has now been in post for more than nine years must contemplate resignation by that date.

There have been strong reactions, both positive and negative. Professor Jean Dausset, the Nobel prize-winning immunologist, has described it as "a good measure", mobility being necessary at all levels of research."Our laboratories are dying of sclerosis", he said. But according to another world-renowned biologist, the measure is "very bad for French science".

In fact, the regulation is not yet law, and may be modified. François Gros, exdirector of the Institut Pasteur and now science adviser to the Prime Minister, Pierre Mauroy, is being urged from all quarters to advise Chevènement against the move.

The chance that such pressure will succeed, however, seems slim. Chevènement has in fact already hardened the proposal from the version which originated from the medical research council, INSERM. INSERM probably suffers more than most French research councils from the longevity of its research directors, some of whom have been in the job for between 20 and 25 years. It was generally agreed that the worst should be shaken out, to leave room for new blood. The question was how?

After long debate stimulated by the new director-general of INSERM (Philippe Lazar, who was rapporteur for the National Colloquium on Science and Technology last January), it was agreed by the directorate, the scientific council and the trade unions at INSERM that the 250 or so posts of scientific director should be limited to four-year terms, renewable twice (for 12 years in all). After that, all agreed that the director of a group could be reconfirmed in his post "in exceptional circumstances". But when the ministry was consulted about the proposal, it insisted that the 12-year term would be final, and that there would be no exceptions.

According to one leading scientist close to the INSERM directorate, the result is a harsh, bureacratic solution to a real problem in France: how to make effective evaluations of scientific progress. "It's

true I've never seen a group leader fired', he said. But the imposition of a rigid 12-year rule is not the answer. Rather, there should be proper, expert evaluation, using both French scientists and scientists from abroad. Many existing INSERM directors should go, he felt; but equally others who had been in place 12 years should stay for the good of science such as the neurophysiologist Jacques Glowinski, or Michel Jouvet (a specialist in sleep mechanisms), both threatened by the new rule.

Unfortunately for French science the whole issue is rapidly becoming politicized, with those resisting the move being classed as rightist. However, left-wing scientists also consider the move hypocritical because it avoids the "democratic" assessment systems set up by the new government. These systems, which involve largely elected committees to make judgements on appointments, grants and so on, are sup-

\title{
Few changes for West Germany
}

\section{Heidelberg}

The new West German Minister of Research and Technology, Dr Heinz Riesenhuber, gave a good impression last week, after 48 hours in office, of having hit the ground running. Once party spokesman on energy, he was obviously familiar with his role, fielding even questions on the fast breeder with confidence and humour.

Riesenhuber holds a PhD (University of Frankfurt, 1965) for work on lattice distortions in microcrystalline iron phosphate. For eleven years, he has been the technical director of a thriving middlesized company specializing in industrial polymers. He entered the Bundestag in 1976 and became chairman of the intraparliamentary committee on energy and environment in 1977.

Last week he stressed the deteriorating national economic situation, the increasing financial burden of the prototype reactors (see Nature 30 September, p.384) and the inertia of large projects which limit the immediate possibility of increasing investment and change. But Riesenhuber sees a positive role for his ministry in the implementation of party research and technology policies (Nature 23 September, p.289).

Nevertheless, Riesenhuber emphasized his commitment to basic research and to continuing support along the lines of the previous administration. But why, he wondered, is world-class investment in basic research not always matched by research results, as assessed by criteria such as the Science Citation Index or Nobel prizes?

The new minister has already carried out an analysis of potential growth areas. Besides microelectronics and biotechnology, materials research, particu- posed to be "transparent" and avoid the formation of cliques and interest groups. But if they are expected to work, why does the government not make use of them to decide whether a group leader should continue or not? The imposition of a rigid rule reduces the power of the committees, and indicates that the government lacks confidence in their decisions.

Whatever final decision is reached on the 12-year rule, INSERM is at pains to smoothe the highly troubled waters. On Monday it released a statement arguing that very few of its directors would be affected (a medical newspaper in Paris last week estimated that $60-70$ positions were under threat); and that the object of the reform was above all "the quality of research". The period between now and the deadline of 31 December 1985 would be one of "intense reflection on how to apply the rule", the statement said.

Robert Walgate

larly high-temperature polymers, was mentioned. (There are suggestions of a new Max Planck Institute for polymer research.)

To promote these key areas, Riesenhuber will encourage closer collaborations with other ministries, research organizations and industry, so as to create "market push" rather than "government pull"'. He plans to take a close look at the country's many large research organizations which, despite their solid research achievement, may not be pulling their weight economically.

Riesenhuber also stressed the importance of integrating risk assessment financial and environmental - at all stages of scientific and technological undertakings. The post factum imposition of controls resulted in expense, delays and environmental damage that increased public disquiet about the role of science and technology in a vulnerable world. This, he says, is the only way to restore public trust in science and technology. How far he succeeds in dispelling the environmentalists' fears, the polls will tell.

By contrast with Riesenhuber's bustle, all was peaceful last week at the sister Ministry of Education and Science where Dorothee Wilms has taken over as minister. But the new administration's decision to put student grants on a loan basis will have far-reaching effects. There are no signs of French expansionism, but, although a general cut of 5 per cent in all expenditure is expected, Gerhard Stoltenburg, the new Finance Minister and himself once a forceful minsiter of scientific research under Kiesinger in the 1969 Christian Democrat government, may yet exempt science and technology and even provide the 5 per cent increase needed to 
cover inflation. Playing for safety, however, Riesenhuber plans also to encourage industry to finance more research. He considers that large projects can be better initiated and carried out by industry than by the cameral system of federal government. It remains to be seen how well he succeeds - and what the consequences would be for the government's own research establishments. Sarah Tooze

\section{Why the lag?}

Why has research in West Germany been a disappointment? Economically, West Germany has been if anything better off than its competitors. But West Germany has problems peculiar to itself, as follows:

- Length of education. Both school and university education take longer in West Germany than elsewhere, so that the average age for beginning a $\mathrm{PhD}$ is 27. The results are expense and loss of some of the most creative years.

- The $\mathrm{PhD}$ is finished at an age when tenured jobs and stability are more attractive than mobility, so grants for travel are undersubscribed.

- Too few untenured posts. Under German employment laws there must be a reason for ending a job. Despite loopholes and contrivances, mobility within the research community is limited.

- Legal responsibility of the Ordinarius $\left(\mathrm{C}_{4}\right)$ professors. By law, responsibility for finance and administration is usually vested only in the $\mathrm{C}_{4}$ professor. This creates a sharply pyramidal hierarchy which deprives other members of staff of responsibility.

- Research budgets of universities are contributed three quarters by the region (Land). This money goes automatically to the $\mathrm{C}_{4}$ professors, who have complete control and who are not subject to review of any kind. Federal money allotted by a normal grant system covers one quarter of university research spending and is the only money allocated subject to review.

- The 1976 university law laid down that all grant money, even when allocated to a specific person for a specific purpose, must be administered by the university. This has spawned a bureaucratic machine which leaves the grant-user trapped in a mesh of regulations and subject to interference. These procedures discourage industry from financing research in the universities.

- Inefficient administration. There is a lack of professionalism in the university administrations and administrators are rarely appointed within university departments to help research staffs and coordinate with the university.

- The numbers of students have soared, but despite overall increased spending, research money per head has fallen.

Polish universities

\section{More signs of latent discontent}

"Universities must not turn into an arena for political games", the Polish government newspaper Rzecspospolita warned as the new term opened on 1 October. Government and party officials were evidently worried that the reassembly of some 400,000 young people in the country's 87 universities and higher colleges could provide a focus for further confrontations - particularly in the atmosphere of heightened tension following the enactment of the new law on trade unions which dissolves all existing union structures (including the 11-million strong Solidarity). In the event, the students, whose own Independent Students' Association (NZS) was outlawed last January, reassembled peacefully, and the problem now facing the universities is not so much the threat of student political action but rather of inaction.

Calling for a "climate of normality" in the universities, the party daily Trybuna Ludu stated last week that "it will be difficult for the academic milieu to fulfil its task if it does not embark on a dialogue on such issues as the new law on higher education, improvement in upbringing and teaching methods, and the future of the student movement"'.

The President of the Council of State, Henryk Jablonski, reiterated this theme when conferring professorial diplomas in Warsaw on 6 October. Normal functioning of society will be impossible, he stressed, if citizens are "inactive", and students should therefore be trained to show "initiative, independent thinking and imagination". A conference of university lecturers from Lower Silesia and Opole went so far as to urge encouraging a "creative" approach by students to political and social studies (courses once more obligatory for all).

The students, however, seem reluctant to embark on dialogue with an academic establishment they no longer trust. Some 30 university rectors, elected under the previous democratic procedures have been replaced under martial law, and, under the political "verification" procedures, some 2 per cent of university staff have failed to meet the required criteria, while more than 5 per cent have been re-employed only conditionally, and $21 / 2$ per cent have had to take up non-teaching jobs within the universities.

"Internal emigration" - passive noncooperation with the political and social life of the country - became widespread among Polish intellectual and creative circles under martial law, and has been widely advocated in underground Solidarity literature. In what appears to be a last-ditch stand to "channel" the aspirations of the students, the authorities are now trying to establish a new students' organization, to replace both the banned
NZS and the party-linked Socialist Union of Polish Students (SZSP), a move that many SZSP activists themselves urge as a way to bring the mass of students back into the party fold.

Trade union law, which effectively put an end to hopes for a return to the liberalizations of $1980-81$ has already moved some Polish students to consider turning their internal emigration into an external one, and to try to continue their studies abroad. Some Western embassies in Warsaw, the British Embassy in particular, have already foreseen this possibility and are granting visas to students only if financial support is assured by a Western sponsor (see p.574). Such sponsors will not prove easy to find. In the United Kingdom, where a Polish Students' Appeal Fund was set up to help students stranded by the declaration of martial law, universities have been generous with free places, but funds for maintenance and such necessities as textbooks are, in the words of $\mathrm{Dr}$ Stanislaw Gomulka of the London School of Economics, "already over-extended".

Vera Rich

\section{Canada's research plans \\ Holding up}

\section{Washington}

Canada's ambitious five-year plan for a rapid growth of investment in research and development is in trouble - but it is surviving present economic difficulties more successfully than almost any other government initiative.

This mixed picture emerges from a report just issued by the Canadian National Research Council (NRC), the government's national laboratory. NRC's budget for the 1981-82 fiscal year fell short of the $\$ 304$ million it said it needed to carry out even the most restrictive of three alter-

OECD data on research and development expenditure

\begin{tabular}{lcc}
\hline Country & Year & $\begin{array}{c}\text { Expenditure as \% } \\
\text { of GDP }\end{array}$ \\
United States & 1980 & 2.49 \\
Switzerland & 1979 & 2.45 \\
Germany & 1979 & 2.27 \\
United Kingdom & 1979 & 2.20 \\
Japan & 1980 & 2.04 \\
Netherlands & 1978 & 1.97 \\
Sweden & 1977 & 1.90 \\
France & 1979 & 1.79 \\
Belgium & 1979 & 1.40 \\
Norway & 1979 & 1.37 \\
Yugoslavia & 1977 & 1.20 \\
Canada & 1981 & $1.18^{\star}$ \\
Finland & 1979 & 1.08 \\
Denmark & 1979 & 0.97 \\
Italy & 1979 & 0.82 \\
Turkey & 1978 & 0.59 \\
Portugal & 1978 & 0.32 \\
Greece & 1980 & 0.18 \\
\hline
\end{tabular}

*The OECD figures include social sciences and humanities research. The figures cited in the text $(1.07$ per cent current and 1.5 per cent goal) do not. 